\title{
Glucagon Immunoreactivity in Plasma from Normal and Dystrophic Mice
}

\author{
B. Ahrén and I. Lundquist \\ Department of Pharmacology, University of Lund, Lund, Sweden
}

Summary. The present investigation was undertaken to determine and characterize glucagon immunoreactivity in plasma from normal NMRI mice and from dystrophic mice and their unaffected littermates of the $129 / \mathrm{ReJ}$ strain. Very young dystrophic mice (6 weeks old) displayed much higher basal levels of plasma glucagon immunoreactivity than normal mice. In contrast, plasma concentrations of insulin and glucose were lower in these dystrophic mice than in normal NMRI mice. The plasma glucagon levels declined with age in both strains during the time-period studied (1.5-5 months). Gel filtration of plasma from dystrophic as well as normal mice on Sephadex G-200 revealed that a large part of the total glucagon immunoreactivity was eluted in fractions containing the immunoglobulins. The amount of the 'true' glucagon part was lower in plasma from normal mice (about $0.2 \mu \mathrm{g} / 1$ ) than in plasma from mice of the dystrophic strain $(0.4-0.5 \mu \mathrm{g} / \mathrm{l})$ ). This finding was indirectly corroborated by the observation that a large intravenous glucose load decreased plasma glucagon by approximately $0.2 \mu \mathrm{g} / 1$ in the non-dystrophic NMRI strain and by about $0.4-0.6 \mu \mathrm{g} / \mathrm{l}$ in the dystrophic strain. Thus, the ability of glucose to suppress glucagon secretion appeared unaffected in the dystrophic mice. Glucose-induced insulin release, however, was considerably impaired in these animals. It is concluded that mice of the dystrophic $129 / \mathrm{ReJ}$ strain have higher plasma levels of 'true' glucagon than mice of the non-dystrophic NMRI strain. Whether the abnormally high plasma glucagon levels in the dystrophic strain, particularly in very young dystrophic mice, might contribute to the development of the muscular dystrophy remains to be elucidated.

Key words: Plasma glucagon, mice, muscular dystrophy, gel filtration, immunoglobulins, glucose, insulin.
A large number of studies in different species have been undertaken in order to measure pancreatic glucagon in plasma by radioimmunological techniques [1-9]. However, it has been difficult to evaluate results from various laboratories because of the different specificity of the various glucagon antisera, crossreaction with extrapancreatic glucagon and with certain globulins present in normal plasma and species differences. Data from the mouse are limited $[8,9]$.

In an earlier study it was observed that the pancreas of a dystrophic mouse strain (129/ReJ) displayed high concentrations of glucagon as measured by radioimmunological and immunohistochemical methods [10]. Moreover, blood glucose levels were low in these dystrophic mice and the release of insulin was disturbed $[10,11]$. To study further the abnormalities of the carbohydrate metabolism in these mice, we have attempted to measure and characterize circulating glucagon immunoreactivity in the dystrophic mice and their unaffected littermates in comparison with normal non-dystrophic NMRI mice.

\section{Materials and Methods}

\section{Animals}

Female 129/ReJ dystrophic mice and their unaffected littermate controls were obtained from the Jackson Laboratory, Bar Harbor, Maine, USA. The dystrophic animals were homozygous for the dystrophic gene (dy/dy), whereas their clinically unaffected littermates were either heterozygous (dy/Dy) or homozygous normals (Dy/Dy). Each dystrophic mouse was housed with its littermate control in an individual cage and fed on a standard pellet diet (Astra-Ewos, Södertälje, Sweden) supplemented with wheat germ and dried milk. A similar diet was given to female mice of the NMRI strain (a non-dystrophic strain, Laboratory Animal Breeding, Laven, Denmark). All animals had free access to food and tap water before and throughout the study. 


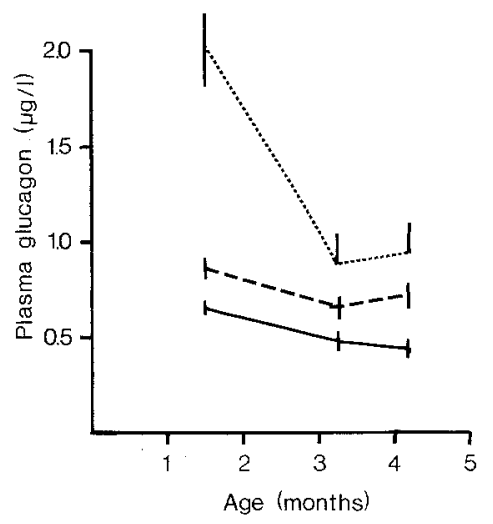

Fig. 1. Basal plasma glucagon immunoreactivity in relation to age in non-dystrophic NMRI mice $(\mathrm{n}=10)(\longrightarrow)$, in dystrophic mice $(\mathrm{n}=19)(\cdots \cdots)$ and their unaffected littermates $(\mathrm{n}=18)$ (-_-_) of the 129/ReJ strain. All data are expressed as mean \pm SEM. There are significant differences between the NMRI mice and the other groups of mice at all time points recorded

\section{Determination of Glucagon Immunoreactivity in Mouse Plasma}

Blood $(100 \mu 1)$ was collected by orbital puncture in unanaesthetised mice into iced tubes containing aprotinin $10 \mu \mathrm{l}(15,000$ kallikrein inactivator units, $\mathrm{KIU} / \mathrm{ml})$. After centrifugation, plasma $(25 \mu \mathrm{l})$ was pipetted into chilled glass tubes containing phosphate buffer $75 \mu \mathrm{l}$ $(0.04 \mathrm{~mol} / 1, \mathrm{pH} 7.4)$ with human serum albumin $1 \mathrm{~g} / 1 ; \mathrm{NaCl}$ $103 \mathrm{mmol} / 1$; aprotinin $200 \mathrm{KIU} / \mathrm{ml}$ and sodium merthiolate $0.59 \mathrm{mmol} / 1$. The tubes were stored at $-20^{\circ} \mathrm{C}$ until analysed. The concentration of glucagon immunoreactivity was measured with alcohol-precipitation of the antibody-bound glucagon immunoreactivity [3] using antiserum K 964 (Novo Research Institute, Copenhagen, Denmark). This antiserum is raised in rabbits and directed against the $\mathrm{C}$-terminal residue of porcine pancreatic glucagon. The antiserum was stored in a phosphate buffer $(0.04 \mathrm{~mol} / \mathrm{l}$, $\mathrm{pH}$ 7.4) with the addition of human serum albumin $1 \mathrm{~g} / 1$ (Behringwerke AG, Marburg, Germany) and used in a final dilution of $1: 2000$. Twice crystallized pork glucagon, used as standard, and ${ }^{125}$ I-labelled porcine glucagon were from Novo Research Institute, Copenhagen, Denmark. They were stored in the phosphate buffer; two standard solutions were also added $\mathrm{NaCl} 103 \mathrm{mmol} / \mathrm{l}$ and aprotinin $200 \mathrm{KIU} / \mathrm{ml}$. In the assay, $25 \mu \mathrm{l}$ samples of this buffer solution, containing human serum albumin $60 \mathrm{~g} / 1$, were added to glucagon $75 \mu \mathrm{l}$ standard solution. The coefficients of variation were: $7.3 \%$ intra-assay $(n=8)$ and $12.9 \%$ interassay $(n=8)$ at the medium range of the standard curve. The lower limit of detection was $10 \mathrm{ng} / \mathrm{l}$.

\section{Determination of Glucagon Immunoreactivity in Gel Filtrated Mouse Plasma}

Pooled plasma $(0.5 \mathrm{ml})$ from NMRI mice, dystrophic mice and unaffected littermates was applied to a Sephadex G-200 column (1.6 $\times 85 \mathrm{~cm}$ ). The plasma was eluted with buffer consisting of glycine sodium hydroxide $(0.2 \mathrm{~mol} / 1, \mathrm{pH} 8.8)$, human serum albumin $2.5 \mathrm{~g} / \mathrm{l}$ and aprotinin $500 \mathrm{KIU} / \mathrm{ml}$. The flow rate was $7.2 \mathrm{ml} / \mathrm{h}$. Filtration was performed at $4^{\circ} \mathrm{C}$, and the fractions $(3.7 \mathrm{ml})$ were stored at $-20^{\circ} \mathrm{C}$ until analysed for content of glucagon immunoreactivity. Absorbance at $280 \mathrm{~nm}$ was recorded for identification of the presence of protein.
For calibration of the column, Blue Dextran (Pharmacia, Uppsala, Sweden), human immunoglobulin (Kabi, Stockholm, Sweden) and ${ }^{125} \mathrm{I}$-glucagon were used. ${ }^{125} \mathrm{I}$-Glucagon was applied twice, first together with plasma $(0.5 \mathrm{ml})$ from NMRI mice and then together with a mixture of human immunoglobulin $12.5 \mathrm{mg}$ and human serum albumin $10 \mathrm{mg}$, in mannitol $0.4 \mathrm{~mol} / 1$, the final volume being $0.5 \mathrm{ml}$. On both occasions ${ }^{125} \mathrm{I}$-glucagon $7.4 \mathrm{ng}$ (specific activity $228 \mu \mathrm{Ci} / \mu \mathrm{g}$ ) was used and the ${ }^{125} \mathrm{I}$-glucagon was recovered in the same elution position.

The concentration of glucagon immunoreactivity in the fractions from the gel filtration was measured by radioimmunoassay using antiserum K 964 . The antiserum, standards and ${ }^{125} \mathrm{I}$-labelled glucagon were from Novo, Copenhagen, Denmark and identical to those used for measuring the glucagon immunoreactivity in plasma. For the purpose of determining glucagon in the gel filtrated fractions, however, they were stored in the glycine buffer. When assaying the fractions, $10 \mu \mathrm{l}$ of a solution of $\mathrm{NaCl} 1.02 \mathrm{~mol} / 1$ was added to $90 \mu \mathrm{l}$ of the fraction content, and to this solution the antiserum and the tracer were added. Tubes without antiserum served as controls for the non-specific precipitation.

\section{Determination of Plasma Immunoreactive Insulin and Plasma Glucose}

Plasma concentrations of immunoreactive insulin were determined by radioimmunoassay [12]. Concentrations of plasma glucose were determined enzymatically [13].

\section{Experiments in Vivo}

D-glucose (British Drug Houses, Poole, UK) was injected IV into a tail vein; $0.22 \mathrm{mmol} /$ mouse was given and the volume load was $10 \mu \mathrm{l} / \mathrm{g}$ body weight. Blood was sampled by orbital puncture in conscious mice [14] immediately before and at different intervals after the injection. In this particular experiment hormone analysis was performed on two $10 \mu \mathrm{l}$ plasma samples. L-Arginine hydrochloride (British Drug Houses, Poole, UK) was injected IV $(2.38 \mathrm{mmol} / \mathrm{kg})$ and blood was sampled immediately before and 2 min after the injection (peak level of glucagon concentration in mouse plasma following a rapid IV injection of $\mathrm{L}$-arginine).

\section{Results}

\section{Determination of Glucagon in Plasma from the Different Strains}

Blood samples were taken from unanaesthetized mice at $1.5,3.5$ and 4.5 months of age and the plasma concentrations of glucagon immunoreactivity were measured. Figure 1 shows the values in the three groups of mice during this time period. It is seen that the plasma concentrations of glucagon were higher in the younger mice than in adults. It can also be seen that the concentrations of glucagon were higher in the $129 / \mathrm{ReJ}$ strain than in non-dystrophic NMRI mice, and that the dystrophic mice had values above their littermate controls. At 1.5 months of age the plasma levels of glucagon, insulin and glucose were recorded (Table 1). It appears that dystrophic mice had low levels of glucose and insulin and high levels of glucagon compared with normal non-dystrophic NMRI mice. 
Table 1. Basal plasma levels of glucose, insulin and glucagon in non-dystrophic NMRI mice and in dystrophic mice and their unaffected littermates of the $129 / \mathrm{ReJ}$ strain at 6 weeks of age

\begin{tabular}{|c|c|c|c|c|c|c|c|}
\hline & $\begin{array}{l}\text { No } \\
\text { of mice }\end{array}$ & $\begin{array}{l}\text { Plasma glucose } \\
(\mathrm{mmol} / \mathrm{l})\end{array}$ & $p$ & $\begin{array}{l}\text { Plasma insulin } \\
(\mathrm{mU} / \mathrm{l})\end{array}$ & $p$ & $\begin{array}{l}\text { Plasma glucagon } \\
(\mu \mathrm{g} / 1)\end{array}$ & $p$ \\
\hline \multirow[t]{2}{*}{ NMRI } & 10 & $6.7 \pm 0.4$ & & $21.0 \pm 3.4$ & & $0.65 \pm 0.03$ & \\
\hline & & & $<0.05$ & & $<0.01$ & & $<0.001$ \\
\hline \multirow[t]{2}{*}{ Dystrophic mice } & 18 & $4.5 \pm 0.1$ & & $9.6 \pm 1.6$ & & $2.01 \pm 0.18$ & \\
\hline & & & NS & & NS & & $<0.001$ \\
\hline Littermates & 19 & $4.1 \pm 0.7$ & & $12.4 \pm 1.6$ & & $0.84 \pm 0.05$ & \\
\hline
\end{tabular}

All data are expressed as mean \pm SEM. NS $=$ not significant

\section{Influences of Aprotinin, Temperature, and Dilution on Determination of Glucagon in Mouse Plasma}

Plasma samples taken with or without the addition of aprotinin and then stored for $6 \mathrm{~h}$ at room temperature had virtually the same glucagon concentration $(0.59$ \pm 0.02 and $0.55 \pm 0.02 \mu \mathrm{g} / 1)$ as samples taken in icechilled tubes with aprotinin $(0.56 \pm 0.02 \mu \mathrm{g} / 1)$ (mean $\pm \mathrm{SEM})$. In addition, $\mathrm{L}$-arginine $(2.38 \mathrm{mmol} / \mathrm{kg})$ was injected IV to stimulate the secretion of glucagon. Plasma samples were taken 2 min after the injection and analysed for glucagon. Arginine induced an increase in plasma glucagon by $0.59 \pm 0.08 \mu \mathrm{g} / 1$ above basal. When the 2 min samples were taken without aprotinin, the increase in plasma concentrations of glucagon was $0.55 \pm 0.10 \mu \mathrm{g} / \mathrm{l}($ mean $\pm \mathrm{SEM})$.

The effect of plasma dilution on the apparent glucagon concentration in mouse plasma is seen in Figure 2. Plasma samples with both high (arginine-stimulated) and low glucagon levels were chosen. The observed values do not deviate significantly from the expected values.

\section{Effects of Glucose on Plasma Concentrations} of Glucagon Immunoreactivity, Immunoreactive Insulin, and Glucose.

D-Glucose $(0.22 \mathrm{mmol} /$ mouse $)$ was injected IV to mice at the age of 5 months. Blood samples were taken immediately before the injection and at different time intervals thereafter. The initial plasma glucose levels were $4.34 \pm 0.15 \mathrm{mmol} / 1$ in dystrophic mice, $4.77 \pm 0.08 \mathrm{mmol} / 1$ in littermates, and $5.46 \pm$ $0.37 \mathrm{mmol} / 1$ (mean $\pm \mathrm{SEM}$ ) in NMRI mice. Figure 3 shows the depression of plasma glucagon by glucose in all three groups of mice to about half of the pre-injection level. The values decreased during the first $30 \mathrm{~min}$ and thereafter stabilised. Also shown are the changes in the levels of plasma insulin and glucose in response to the glucose injection: insulin release was greatest in the non-dystrophic NMRI strain. It should

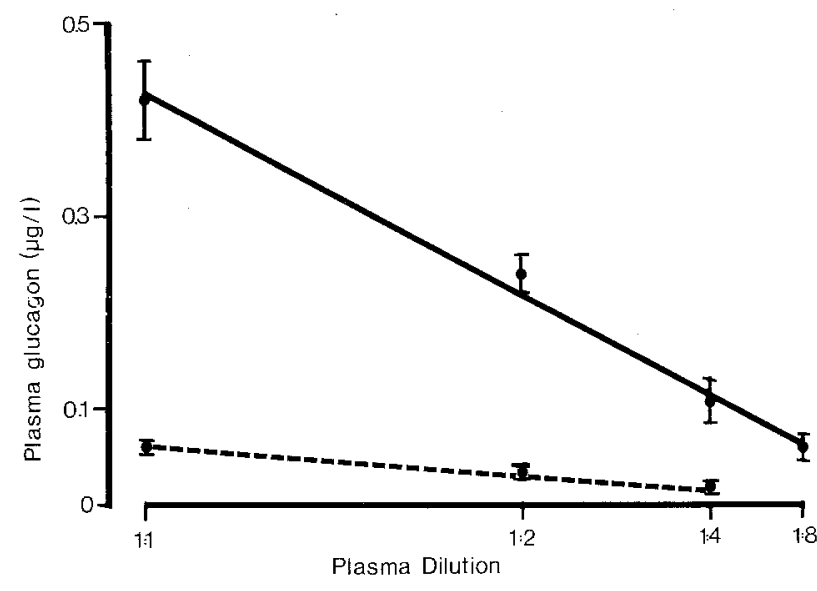

Fig. 2. Effect of dilution on apparent glucagon concentration in plasma from non-dystrophic NMRI mice. Basal (----) and arginine-stimulated $(\longrightarrow$ ) plasma pools are used. Each point represents the mean \pm SD of five determinations

be noted that this large insulin release in the NMRI mice was obtained with a lower total dose of glucose (Fig. 3), since each mouse received the same glucose load $(0.22 \mathrm{mmol} / \mathrm{mouse})$ and the body-weight of the NMRI mice was generally somewhat higher than that of the $129 / \mathrm{ReJ}$ mice. Calculation of the glucose elimination rate ( $k$-value) in the dystrophic animals $(k=$ $2.79 \pm 0.24)$ and their littermates $(k=4.84 \pm 0.66)$ (mean \pm SEM) demonstrated a significant impairment of glucose tolerance in the dystrophic mice $(p<$ $0.025)$. The $k$-value for NMRI mice could not be accurately calculated in the present experiment because in some of these mice initial plasma glucose levels had already been reached after $15 \mathrm{~min}$ (Fig. 3).

\section{Gel Filtration of Plasma}

Pooled plasma from the three different groups of mice, $0.5 \mathrm{ml}$ from each, was applied to a Sephadex G200 column and eluted with glycine buffer (Fig. 4). All three groups displayed immunoassayable glucagon 

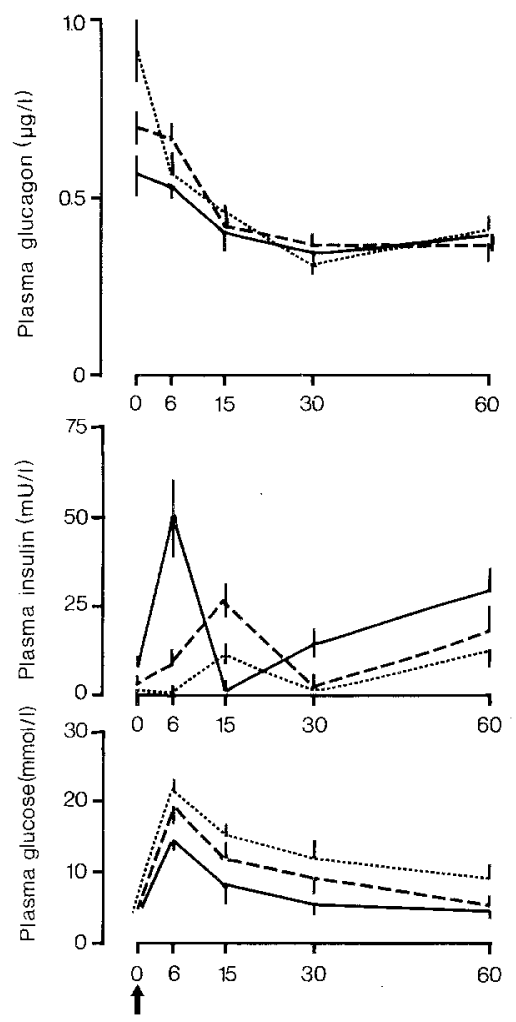

Glucose injection

Time (min)

Fig. 3. Effects of IV glucose $(0.22 \mathrm{mmol} /$ mouse $)$ on plasma concentrations of glucagon immunoreactivity, immunoreactive insulin, and glucose, in non-dystrophic NMRI mice (-), in dystrophic mice $(\cdots \cdot)$ and their unaffected littermates (-.--) of the 129/ ReJ strain. All data are expressed as mean \pm SEM. $(n=10$ for each group)

in the fractions where glucagon should be eluted, according to the elution profile of ${ }^{125} \mathrm{I}$-glucagon. The total glucagon content in these fractions was $98 \mathrm{pg}$ for non-dystrophic NMRI mice (Fig. 4A), $257 \mathrm{pg}$ for the dystrophic mice (Fig. 4B) and 207 pg for their unaffected littermates (Fig. 4C).

All three groups also had a large quantity of glucagon immunoreactivity in the fractions where the immunoglobulins were eluted. The total amount of glucagon immunoreactivity in these fractions was $696 \mathrm{pg}$ for NMRI mice, $527 \mathrm{pg}$ for dystrophic mice, and $453 \mathrm{pg}$ for their unaffected littermates.

\section{Determination of Glucagon Immunoreactivity in Solutions of Human Immunoglobulin}

Since glucagon immunoreactivity was found in fractions containing immunoglobulins, solutions with known concentrations of human immunoglobulins were made in glycine buffer and glucagon immunoreactivity was recorded. Figure 5 shows that human immunoglobulins display glucagon immunoreactivi-
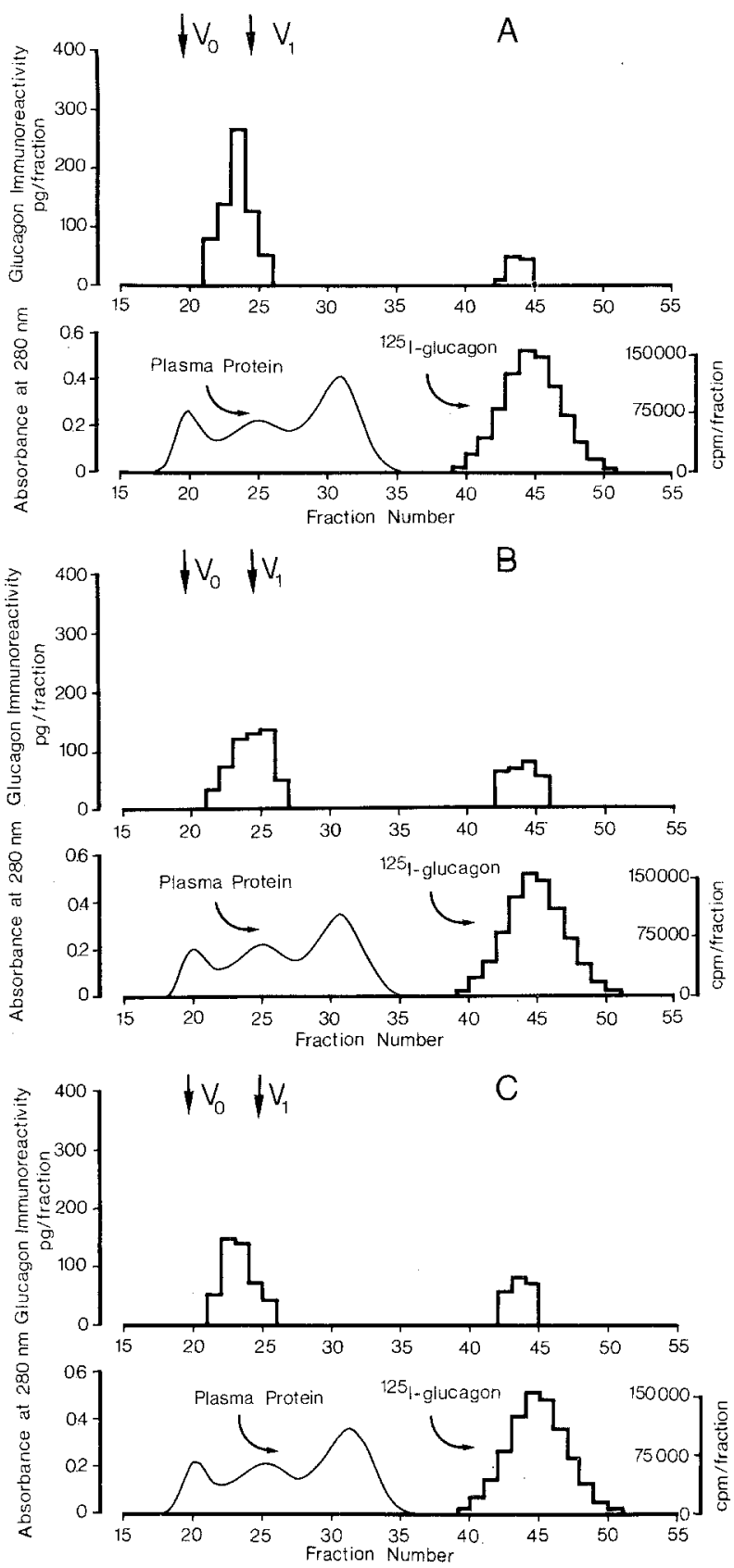

Fig. 4. Sephadex G-200 gel chromatograms of glucagon immunoreactivity in plasma from non-dystrophic NMRI mice (A), from dystrophic mice (B) and their unaffected littermates (C) of the 129/ ReJ strain. Arrows indicate the elution volume of blue dextran $\left(V_{0}\right)$ and human immunoglobulin $\left(\mathrm{V}_{1}\right)$. Filtration profiles of plasma proteins and ${ }^{125} \mathrm{I}$-glucagon are also indicated

ty and that this immunoreactivity is dependent upon immunoglobulin concentration. However, after addition of similar amounts of human immunoglobulins to mouse plasma, recovery of the glucagon immunoreactivity was reduced (Fig. 5). Apparently circulating concentrations of immunoglobulins $(20 \mathrm{mg} / \mathrm{ml})$ may contribute to basal assayable glucagon immunoreactivity in plasma. 


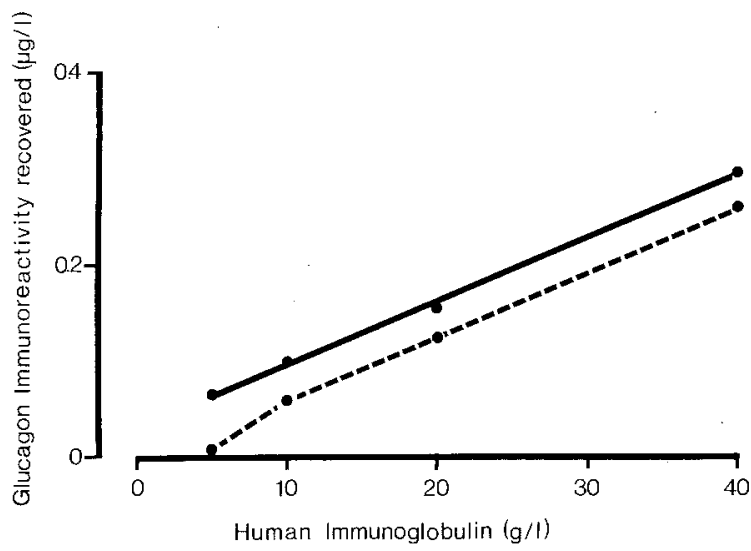

Fig.5. Dose related increase in glucagon immunoreactivity by reactants in human immunoglobulins added to glycine buffer ( - ) or added to mouse plasma in the routine assay $(-----)$

\section{Discussion}

The present study shows that it is possible to assay glucagon in small samples of plasma $(10-25 \mu \mathrm{l})$ from individual small animals such as the mouse. Since unknown reactants in plasma immunoglobulins apparently interfere in the assay of the basal plasma glucagon levels, it seems advisable to measure and calculate the acute changes in plasma glucagon from basal values rather than the absolute values when studying glucagon release mechanisms in these small animals in vivo.

Chromatography of mouse plasma revealed that a large part of the glucagon immunoreactivity was eluted in fractions containing the immunoglobulins, and only a minor part in the fractions where the ${ }^{125} \mathrm{I}$ glucagon was eluted. Thus, the chromatogram suggests that the immunoglobulins in mouse plasma may cross-react with the glucagon antiserum. However, the data do not exclude the possibility that moieties different from the immunoglobulins, although of similar size, could be responsible for this large glucagon immunoreactive fraction. An interference of human immunoglobulins with glucagon antisera has been reported previously [6], and is further demonstrated by the 'standard curves' obtained when measuring glucagon immunoreactivity in solutions containing human immunoglobulins (Fig. 5). Since only a certain fraction of the glucagon immunoreactivity in immunoglobulins added to plasma was recovered in the assay, it is conceivable that when plasma glucagon is assayed, the ratio: "'true' glucagon/glucagon immunoreactivity in immunoglobulins", is not as small as would be suggested by the gel filtration studies, i. e. part of the glucagon immunoreactivity in the immunoglobulins seems to be masked in plasma.
The fractions containing immunoglobulins may consist of 'big plasma glucagon' [15] or the 'interference factor' [16]. These are both high molecular weight factors reacting with glucagon antisera, but their relation to glucagon and glucagon metabolism or to immunoglobulins is not fully established. It should also be noted that immunoglobulins interfere with the radioimmunoassay of gastrin [17].

Dystrophic mice, and their littermate controls, had higher values of plasma glucagon immunoreactivity than normal, non-dystrophic NMRI mice. The results from the gel filtration studies were similar to those in the non-dystrophic NMRI mice, in that more than half of the total plasma glucagon was obtained in fractions containing immunoglobulins. However, the dystrophic mice and their littermates had larger amounts of glucagon than NMRI mice. Although it is still possible that these fractions may contain immunoreactive peptides of about the same size as glucagon, it is likely that the higher values of immunoreactive glucagon in the dystrophic mice reflect truly greater levels of circulating glucagon. Such an increase in the dystrophic mice may be consistent with our recent observations of a higher concentration of glucagon in the pancreas and a greater number of glucagon cells in the islets of the $129 / \mathrm{ReJ}$ strain than in the non-dystrophic NMRI strain [10]. Moreover it is noteworthy that the apparent glucagon immunoreactivity of the immunoglobulins in the non-dystrophic NMRI strain was higher than in the dystrophic 129/ ReJ strain although the total amount of serum proteins, as revealed by the protein elution profile, seemed to be similar to the normal non-dystrophic NMRI mice (Fig.4). It is similarly of interest that muscular dystrophic chickens have reduced levels of IgG but maintain normal levels of total serum proteins, IgA and IgM when compared with normal nondystrophic chickens [18].

The dystrophic mice were shown to have lower plasma glucose concentrations than normal NMRI mice $[10,11]$, and very young dystrophic mice also displayed lower plasma insulin. Apparently the dystrophic mice have an unusual insulin/glucagon balance with a low insulin and a high glucagon level in plasma and, despite this, have a low plasma glucose level. Furthermore, the dystrophic strain had a low and delayed insulin release in response to glucose (Fig. 3). In earlier studies, other abnormalities in the insulin releasing mechanisms of the dystrophic mice have been demonstrated [10, 11]. Apart from glucose-induced insulin release, insulin secretion stimulated by the sulphonylurea agent glibenclamide is low, whereas insulin release induced by the $\beta$-adrenoceptor agonist isopropylnoradrenaline is enhanced $[10,11]$. Whether stimulation of glucagon secretion in these mice will 
reveal any abnormalities in glucagon release remains to be established. However, the very high plasma glucagon levels measured in young dystrophic animals do indeed suggest abnormal regulation of basal glucagon secretion.

Glucose inhibits the release of glucagon [19], and we showed that, 30-60 min after an IV injection of a large dose of glucose, the concentrations of plasma glucagon were depressed in all three groups of mice (Fig.3). This decrease was about $0.2 \mu \mathrm{g} / \mathrm{l}$ in normal mice and $0.4-0.6 \mu \mathrm{g} / \mathrm{l}$ in dystrophic mice. These values are in fair agreement with the gel filtration glucagon values of approximately $0.2 \mu \mathrm{g} / 1$ plasma, eluted in the glucagon zone in normal mice, and $0.4-0.5 \mu \mathrm{g} / 1$ in the dystrophic strain. It cannot be excluded that the remaining part of the initial basal glucagon immunoreactivity is the cross-reacting factor(s) found in fractions containing immunoglobulins in the chromatographic study, since in vitro studies with the perfused pancreas have shown that introduction of a glucose concentration as small as $5 \mathrm{mmol} / 1$ causes total inhibition of glucagon secretion [20].

In summary, the dystrophic mouse strain $129 / \mathrm{ReJ}$ displays abnormally high levels of plasma immunoreactive glucagon. Mice with overt muscular dystrophy have higher plasma glucagon levels than their unaffected littermates. Gel filtration studies suggest that the dystrophic strain indeed has higher plasma concentrations of true glucagon than the non-dystrophic NMRI strain. A large part of the basal plasma glucagon in both strains consists of unknown reactants in the immunoglobulin fraction. Whether the observed abnormalities of plasma glucagon values in the dystrophic $129 /$ ReJ strain, particularly in very young dystrophic mice, may contribute, directly or indirectly, to the development of their muscular dystrophic disease remains to be elucidated.

Acknowledgements: The authors express their appreciation to L. Kvist and P.Okmark for technical assistance and to E. Björkbom for secretarial help. This study was supported by the Swedish Medical Research Council (14P-4289, 14X-4286) and by grants from the Medical Faculty, University of Lund, Sweden and Nordisk Insulinfond, Gentofte, Denmark.

\section{References}

1. Unger RH, Eisentraut AM, McCall MS, Keller S, Lanz H-C, Madison LL (1959) Glucagon antibodies and their use for immunoassay for glucagon. Proc Soc Exp Biol Med 102: 621-623

2. Eisentraut A, Ohneda A, Panada E, Unger RH (1968) Immunologic discrimination between pancreatic glucagon and enteric glucagon-like immunoreactivity (GLI) in tissue and plasma. Diabetes 17: 321-322
3. Heding LG (1971) Radioimmunological determination of pancreatic and gut glucagon in plasma. Diabetologia 7: 10-19

4. Alford EP, Bloom SR, Nabarro JDN (1977) Glucagon levels in normal and diabetic subjects: use of a specific immunoabsorbent for glucagon radioimmunoassay. Diabetologia 13:1-6

5. Holst JJ, Aasted B (1974) Production and evaluation of glucagon antibodies for radioimmunoassay. Acta Endocrinol (Copenh) $77: 715-726$

6. von Schenk H (1977) Production and characterization of an antiserum against pancreatic glucagon. Clin Chim Acta 80: $455-463$

7. Weir G (1977) Assessment of glucagon immunoreactivity in plasma. In: Foà PP, Bajaj JS, Foà NL (eds) Glucagon: its role in physiology and clinical medicine, Springer-Verlag, New York Heidelberg Berlin pp 65-76.

8. Cuendet GS, Loten EG, Cameron DP, Renold AE, Marliss EB (1975) Hormone-substrate responses to total fasting in lean and obese mice. Am J Physiol 228: 276-283

9. Lavine RL, Voyles N, Perrino PV, Recant L(1975) The effect of fasting on tissue cyclic AMP and plasma glucagon in the obese hyperglycemic mouse. Endocrinology 97:615-620

10. Lundquist I, Håkanson R, Harris JB, Libelius R, Sundler F (1979) Endocrine pancreas in the dystrophic mouse. Ann NY Acad Sci 317: 206-220

11. Lundquist I, Harris JB (1979) Insulin secretion and carbohydrate metabolism in the dystrophic mouse. Europ J Pharmacol $53: 365-373$

12. Heding L (1966) A simplified insulin radioimmunoassay method. In: Donato L, Milhaud G, Sirchis J (eds) Labelled proteins in tracer studies. Euratom, Brussel pp 345-350

13. Bruss ML, Black AL (1978) Enzymatic microdetermination of glycogen. Anal Biochem 84: 309-312

14. Rerup C, Lundquist I (1966) Blood glucose level in mice I. Evaluation of a new technique of multiple serial sampling. Acta Endocrinol (Copenh) 52:357-367

15. Valverde I, Villanueva ML, Lozano I, Marco J (1974) Presence of glucagon immunoreactivity in the globulin fraction of human plasma ("big plasma glucagon"). J Clin Endocrinol Metab 39: 1090-1098

16. Weir GC, Knowlton SD, Martin DB (1975) High molecular weight glucagon-like immunoreactivity in plasma. J Clin Endocrinol Metab 40: 296-302

17. Rehfeld JF, Schwartz TW, Stadil F (1977) Immunochemical studies on macromolecular gastrins. Evidence that "big big gastrins" are artifacts in blood and mucosa but truly present in some large gastrinomas. Gastroenterology 73: 469-477

18. Sanders BG, Kline K (1977) IgG immunoglobulin deficiency in muscular dystrophic chickens. J Heredity $68: 55-56$

19. Unger RH, Orci L (1976) Physiology and pathophysiology of glucagon. Physiol Rev 56:779-826

20. Grodsky GM, Fanska R, Lundquist I (1975) Interrelationships between $\alpha$ and $\beta$-anomers of glucose affecting both insulin and glucagon secretion in the perfused rat pancreas. Endocrinology 97: 573-580

Received: 24 February 1981

and in revised form: 17 November 1981

Dr. Bo Ahrén

Department of Pharmacology

Sölvegatan 10

S-223 62 Lund, Sweden 